\title{
KUALITAS PELAYANAN TERHADAP KEPUASAN DAN LOYALITAS NASABAH PADA BANK XYZ
}

\author{
Khoerul Umah \\ Program Studi Magister Manajemen Universitas Tarumanagara \\ umah22@gmail.com
}

\begin{abstract}
Communities are increasingly selective in choosing banking services to place their own funds in order to avoid the risk of loss due to poor performance of a bank. Quality services can increase the satisfaction and loyalty of the company so it is expected to encourage the company's success to win the competition. This study aims to analyze the effect of service quality variables consisting of dimensions of reliability, responsiveness, assurance, empathy, and physical evidence of customer satisfaction and loyalty. Data analysis used multiple linier regression analysis method with 100 bank customer XYZ sample as respondent. The sampling technique using simple random sampling. Validity and reliability tests are used in testing of research instruments as well as testing classical assumptions in the form of normality test, heterokedastisity test, and linearity test. The results showed that the quality of service has a positive and significant impact on loyalty through customer satisfaction and satisfaction have a positive and significant impact on customer loyalty.
\end{abstract}

Keywords : Service Quality, Customer Satisfaction, Customer Loyalty

\section{PENDAHULUAN}

Lembaga perbankan merupakan inti dari sistem keuangan suatu Negara. Bank merupakan lembaga keuangan yang menjadi tempat bagi orang perseorangan, badan-badan usaha swasta, badan-badan usaha milik Negara, bahkan lembaga-lembaga pemerintahan menyimpan dana-dana yang dimilikinya. Setelah mengumpulkan dana, maka bank menyalurkan dana tersebut melalui kegiatan perkreditan dan berbagai jasa yang diberikan oleh bank. Bank melayani kebutuhan pembiayaan serta melancarkan mekanisme sistem pembayaran bagi semua sektor perekonomian. Menurut Kamus Besar Bahasa Indonesia, Bank adalah usaha dibidang keuangan yang menarik dan mengeluarkan uang dimasyarakat, terutama pemberian kredit dan jasa di lalu lintas pembayaran dan peredaran uang.

Penilaian masyarakat terhadap bank dipengaruhi oleh bagaimana masyarakat tersebut memaknai produk bank atau pelayanan yang diterima. Menurut Bedi (2010) memberikan layanan yang berkualitas tinggi adalah suatu keharusan untuk mencapai kepuasan pelanggan. Kualitas pelayanan dan kepuasan pelanggan berasal dari layanan yang terorganisir. Terciptanya kepuasan pelanggan atau nasabah dapat menjadikan hubungan antar penyedia jasa dan pelanggannya harmonis, yang selanjutnya akan menciptakan loyalitas pelanggan dan akhirnya menguntungkan bagi perusahaan. Dengan system dan pelayanan yang berkualitas, maka nasabah akan merasa puas sehingga akan mempertahankan dan meningkatkan loyalitas nasabah terhadap perusahaan.

\section{TELAAH KEPUSTAKAAN \\ Kualitas Pelayanan}

Kualitas pelayanan telah dikonseptualisasikan sebagai perbedaan antara harapan pelanggan mengenai pelayananyang akan diterima dan persepsijasa yang diterima (Parasuramanet al. dalam Akbar dan Parves, 2009). Dimensi kualitas pelayanan dapat diidentifikasi melalui penelitian yang dilakukan oleh Parasuraman et al. yang dikenal sebagai SERVQUAL (Kotler dan Keller, 2007:56), sebagai berikut : 
1 Bukti Fisik (Tangibles)

Berupa penampilan fasilitas fisik, peralatan, dan berbagai materi komunikasi. Penampilan, sarana, dan prasarana fisik perusahaan serta keadaan lingkungan sekitarnya adalah bukti nyata dari pelayanan yang diberikan oleh pemberi jasa.

2 Keandalan (Reliability)

Kemampuan untuk memberikan jasa sesuai dengan yang dijanjikan, terpercaya, akurat, konsisten, dan sesuai dengan harapan. Sesuai dengan harapan pelanggan berarti kinerja yang tepat waktu, pelayanan tanpa kesalahan, sikap simpatik, dan akurasi tinggi.

3 Daya Tanggap (Responsiveness)

Kemauan dari karyawan dan pengusaha untuk membantu pelanggan dan memberikan jasa dengan cepat serta mendengar dan mengatasi keluhan yang diajukan pelanggan, misalnya kesigapan karyawan dalam melayani pelanggan, kecepatan dalam proses transaksi, dan penanganan keluhan pelanggan.

4 Jaminan (Assurance)

Kemampuan karyawan untuk menimbulkan keyakinan dan kepercayaan terhadap janji yang telah dikemukakan kepada konsumen, misalnya kemampuan karyawan atas: pengetahuan terhadap produk secara tepat, kualitas keramah-tamahan, perhatian, dan kesopanan dalam memberi pelayanan, keterampilan dalam memberikan informasi, kemampuan dalam memberikan keamanan di dalam memanfaatkan jasa yang ditawarkan, dan kemampuan dalam menanamkan kepercayaan pelanggan terhadap perusahaan.

$5 \quad$ Empati (Empathy)

Kesediaan karyawan dan pengusaha memberikan perhatian mendalam dan khusus kepada pelanggan dengan berupaya memahami keinginan pelanggan dimana suatu perusahaan diharapkan memiliki suatu pengertian dan pengetahuan tentang pelanggan dan memahami kebutuhan pelanggan secara spesifik.

\section{Kepuasan}

Saat ini kepuasan nasabah menjadi fokus perhatian oleh hampir semua pihak baik pemerintah, pelaku bisnis, dan konsumen. Hal ini disebabkan semakin baiknya pemahaman atas konsep kepuasan nasabah sebagai strategi untuk memenangkan persaingan di dunia bisnis. Kata 'kepuasan atau satisfaction' berasal dari Bahasa Latin "satis" (artinya cukup baik, memadai) dan "facio" (melakukan atau membuat). Secara sederhana kepuasan diartikan sebagai 'upaya pemenuhan sesuatu atau membuat sesuatu memadai (Tjiptono, 2007:349). Howard dan Sheth dalam Tjiptono (2007:349) mengungkapkan bahwa kepuasan pelanggan adalah situasi kognitif pembeli yang berkenaan dengan kesepadanan atau ketidaksepadanan antara hasil yang didapatkan dengan pengorbanan yang dilakukan.

\section{Loyalitas}

Loyalitas merupakan istilah kuno yang secara tradisional telah digunakan untuk melukiskan kesetiaan dan pengabdian antusias kepada negara, cita-cita, atau individu. Dalam konteks bisnis belakangan ini, istilah loyalitas telah digunakan untuk melukiskan kesediaan pelanggan untuk terus berlangganan pada sebuah perusahaan dalam jangka panjang, dengan membeli dan menggunakan barang serta jasanya secara berulang-ulang dan lebih baik lagi secara eksklusif, dan dengan sukarela merekomendasikan produk perusahaan tersebut kepada temanteman dan rekan-rekannya (Lovelock dan Wright, 2007:133).

Efek loyalitas bagi perusahaan adalah memberikan sumber pendapatan terusmenerus dalam kurun waktu bertahun-tahun. Perlu digarisbawahi bahwa, loyalitas hanya akan berlanjut sepanjang pelanggan merasakan bahwa mereka menerima nilai yang lebih baik (termasuk kualitas yang lebih tinggi) dibandingkan dengan yang dapat diperoleh dengan beralih kepada penyedia jasa lain. 


\section{Penelitian Terdahulu}

1. Dalam jurnalnya Generic Technology-based service quality dimensions in banking impact on customer satisfaction and loyalty yang dimuat dalam International Journal of Bank Marketing Vol. 29 No. 2, 2011, Shirshendu Ganguli dan Sanjit Kumar Roy menganalisis hubungan antara kualitas pelayanan, teknologi informasi dalam industri perbankan dengan kepuasan nasabah dan loyalitasnya.

2. Penelitian yang dilakukan oleh Al-Rousan, M. Ramzi, Badaruddin Mohamed yang berjudul Customer Loyalty and the Impacts of Service Quality: The Case of Five Star Hotels in Jordan, dan dimuat dalam journal of Business and Economic Sciences, Vol. 5, pp. 202-208, 2010. Penelitian ini menganalisis dampak dari kualitas pelayanan terhadap loyalitas pelanggan.

\section{Kerangka Pemikiran}

Mosahab et al. (2010) menyebutkan bahwa perubahan kepuasan pelanggan berhubungan dengan kualitas pelayanan di mana kualitas pelayanan memiliki hubungan langsung dengan loyalitas. oleh karena itu pada penelitian ini, penulis ingin mengetahui apakah terdapat hubungan antara kualitas pelayanan yang mempengaruhi kepuasan dalam meningkatkan loyalitas nasabah Bank XYZ.

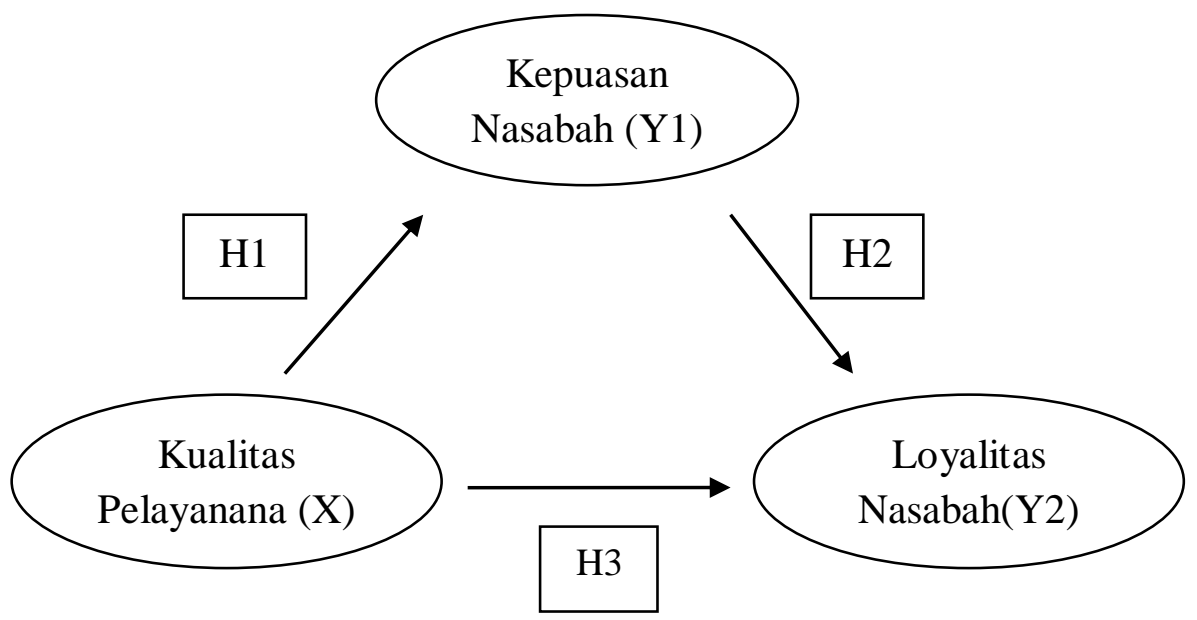

Gambar 1 Kerangka Pemikiran

\section{Hipotesis Penelitian}

Hipotesis dalam penelitian ini adalah sebagai berikut:

H1 : Kualitas pelayanan berpengaruh positif dan signifikan terhadap kepuasan nasabah Bank XYZ

H2 : Kepuasaan berpengaruh positif dan signifikan terhadap loyalitas nasabah Bank XYZ.

$\mathrm{H} 3$ : Kualitas pelayanan berpengaruh positif dan signifikan terhadap loyalitas nasabah Bank $\mathrm{XYZ}$

\section{METODE PENELITIAN}

\section{Populasi dan Sampel}

Populasi dalam penelitian ini adalah seluruh nasabah pada Bank XYZ, baik nasabah deposito, tabungan, maupun kredit. Jumlah sampel yang digunakan sebanyak 100 responden. Pertimbangan yang digunakan dalam memilih responden yaitu: 
1. Responden adalah nasabah dengan tingkat pendidikan minimal SMA atau sederajat dengan pertimbangan nasabah tersebut mampu memahami butir-butir pernyataan dan mampu untuk memberikan pendapat terhadap pernyataan dalam kuesioner.

2. Responden adalah nasabah deposito, tabungan dan kredit Bank XYZ dengan lama menjadi nasabah minimal enam bulan. Pertimbangan tersebut didasarkan karena nasabah tersebut adalah nasabah yang paling sering bertransaksi dan berinteraksi dengan staf Baank XYZ sehingga lebih mengenal serta mengetahui kualitas pelayanan Bank XYZ.

\section{Variabel Penelitian dan Operasional Variabel}

Variabel penelitian terdiri dari 2 macam, yaitu:

1. Variabel bebas (independent)

Tipe variabel yang menjelaskan atau mempengaruhi variabel yang lain. Variabel independent dalam penelitian ini adalah dimensi kualitas pelayanan yang terdiri dari tangible (bukti fisik), reliability (kahandalan), responsiveness (daya tanggap), assurance (jaminan), emphaty (empati).

2. Variabel terikat (dependent)

Variabel terikat adalah tipe variabel yang dijelaskan atau dipengaruhi oleh varibel independent. Variabel dependent dalam penelitian ini adalah kepuasan nasabah dan loyalitas nasabah.

Operasional variabel adalah mendefenisikan sebuah konsep sehingga dapat diukur dengan melihat faktor dimensi perilaku, karakter atau hal-hal yang melandasi sebuah konsep tersebut

Tabel 1. Operasional Variabel

\begin{tabular}{|c|c|c|c|}
\hline Variabel & Definisi & Indikator & $\begin{array}{c}\text { Skala } \\
\text { Pengukuran }\end{array}$ \\
\hline Kualitas layanan & $\begin{array}{l}\text { Kesesuaian } \\
\text { antara harapan atau } \\
\text { keinginan konsumen } \\
\text { dengan persepsi } \\
\text { konsumen. }\end{array}$ & $\begin{array}{l}\text { - Tangibles } \\
\text { - Empathy } \\
\text { - Responsiveness } \\
\text { - Reliability } \\
\text { - Assurance }\end{array}$ & Skala Likert \\
\hline $\begin{array}{l}\text { a. Tangibles } \\
\text { (bukti fisik) }\end{array}$ & $\begin{array}{l}\text { Meliputi fasilitas fisik } \\
\text { (Banking hall) serta } \\
\text { perlengkapan } \\
\text { karyawan } \\
\text { (Penampilan) }\end{array}$ & $\begin{array}{l}\text { - Ruangan yang bersih \& } \\
\text { nyaman } \\
\text { - Fasilitas kantor yang lengkap } \\
\text { - kerapihan pakaian frontliner }\end{array}$ & Skala Likert \\
\hline $\begin{array}{l}\text { b.Responsivenes } \\
\text { s (ketanggapan) }\end{array}$ & $\begin{array}{l}\text { Kemampuan untuk } \\
\text { menolong pelanggan } \\
\text { dan kesediaan untuk } \\
\text { melayani pelanggan } \\
\text { dengan baik. }\end{array}$ & $\begin{array}{l}\text { - Memberikan pelayanan } \\
\text { dengan akurat dan tepat } \\
\text { - Menaympaikan info secara } \\
\text { jelas } \\
\text { - Tindakan cepat pada saat } \\
\text { konsumen membutuhkan }\end{array}$ & Skala Likert \\
\hline $\begin{array}{l}\text { c. Reliability } \\
\text { (keandalan) }\end{array}$ & $\begin{array}{l}\text { Kemampuan untuk } \\
\text { melakukan pelayanan } \\
\text { sesuai dengan yang } \\
\text { dijanjikan, akurat, } \\
\text { dan memuaskan. }\end{array}$ & $\begin{array}{l}\text { - Karyawan memberikan } \\
\text { pelayanan yang cepat } \\
\text { - Karyawan memberikan } \\
\text { pelayanan tanpa kesalahan } \\
\text { - Perlakuan yang sama atau } \\
\text { adil kepada semua konsumen }\end{array}$ & Skala Likert \\
\hline $\begin{array}{l}\text { d. Assurance } \\
\text { (jaminan) }\end{array}$ & $\begin{array}{l}\text { Pengetahuan, } \\
\text { kesopanan petugas } \\
\text { serta sifatnya yang }\end{array}$ & $\begin{array}{l}\text { - Pengetahuan layanan } \\
\text { terhadap jenis layanan dan }\end{array}$ & Skala Likert \\
\hline
\end{tabular}




\begin{tabular}{|c|c|c|c|}
\hline & $\begin{array}{l}\text { dapat dipercaya } \\
\text { sehingga pelanggan } \\
\text { bebas dari resiko. } \\
\text { (Philip Kotler, 2007) }\end{array}$ & $\begin{array}{l}\text { produk } \\
\text { - Keramah tamahan dan } \\
\text { kesopanan karyawan dalam } \\
\text { pelayanan } \\
\text { - Kemampuan karyawan dalam } \\
\text { menumbuhkan kepercayaan dari } \\
\text { nasabah }\end{array}$ & \\
\hline $\begin{array}{l}\text { e. Emphaty } \\
\text { (empati) }\end{array}$ & $\begin{array}{l}\text { Rasa peduli untuk } \\
\text { memberikan } \\
\text { perhatian secara } \\
\text { individual kepada } \\
\text { pelanggan, } \\
\text { memahami } \\
\text { kebutuhan pelanggan }\end{array}$ & $\begin{array}{l}\text { - Memberikan perhatian } \\
\text { kepada nasbah } \\
\text { - Memahami kebutuhan } \\
\text { nasabah } \\
\text { - Perhatian terhadap keluhan } \\
\text { nasabah }\end{array}$ & Skala Likert \\
\hline $\begin{array}{l}\text { Kepuasan } \\
\text { Nasabah (Y1) }\end{array}$ & $\begin{array}{l}\text { Hasil yang dirasakan } \\
\text { oleh pembeli yang } \\
\text { mengalami kinerja } \\
\text { sebuah perusahaan } \\
\text { yang sesuai dengan } \\
\text { harapannya. } \\
\text { (Philip Kotler, 2007) }\end{array}$ & $\begin{array}{l}\text { - Kepuasan dalam pemakaian } \\
\text { produk Bank XYZ } \\
\text { - Kepuasan dalam pelayanan } \\
\text { Bank XYZ } \\
\text { - Kepuasan dalam } \\
\text { menginformasikan produk Bank } \\
\text { XYZ }\end{array}$ & Skala Likert \\
\hline $\begin{array}{l}\text { Loyalitas } \\
\text { Nasabah (Y2) }\end{array}$ & $\begin{array}{l}\text { Kesediaan pelanggan } \\
\text { untuk terus } \\
\text { berlangganan pada } \\
\text { sebuah perusahaan } \\
\text { dalam jangka } \\
\text { panjang, } \\
\text { (Lovelock dan } \\
\text { Wright, 2007:133). }\end{array}$ & $\begin{array}{l}\text { - Pertimbangan untuk terus } \\
\text { bertransaksi di Bank XYZ } \\
\text { - Merekomendasikan Bank } \\
\text { XYZ pada orang lain } \\
\text { - Berbicara hal positif tentang } \\
\text { Bank XYZ }\end{array}$ & Skala Likert \\
\hline
\end{tabular}

\section{Metode Analisis Data}

Analisis yang digunakan dalam penelitian adalah sebagai berikut :

1.

Uji validitas digunakan untuk mengetahui sah atau valid tidaknya suatu kuesioner. Suatu kuesioner dikatakan valid jika pertanyaan pada kuesioner mampu untuk mengungkapakan sesuatu yang akan diukur oleh kuesioner tersebut.

2.

Uji Reliabilitas

Reliabilitas adalah data untuk mengukur suatu kuesioner yang merupakan indikator dari variabel atau konstruk. Suatu kuesioner dikatakan reliabel atau handal jika jawaban seseorang terhadap pertanyaan adalah konsisten atau stabil dari waktu ke waktu.

3. Uji Multikolineritas

Uji multikolineritas bertujuan menguji apakah dalam model regresi ditemukan adanya korelasi antar variabel bebas model regresi yang baik seharusnya tidak terjadi korelasi diantara variabel bebas jika variabel bebas berkorelasi maka variable-variabel ini tidak ortogonal. Variabel ortogonal adalah variabel bebas yang nilai korelasi antar sesama variabel bebas $=0$.

\section{Teknik Pengujian Hipotesis}


1.

Analisis

regresi linier

berganda

Analisis regresi linier berganda adalah analisis regresi yang menjelaskan hubungan antara variabel independen dengan variabel dependen. Persamaan linear berganda yang dipakai pada penelitian ini adalah sebagai berikut:

$\mathrm{Y} 1=\mathrm{b} 0+\mathrm{b} 1 \mathrm{X}+\mathrm{e}$ dan

$\mathrm{Y} 2=\mathrm{b} 0+\mathrm{b} 1 \mathrm{X}+\mathrm{b} 2 \mathrm{Y} 1+\mathrm{e}$

Keterangan :

$\begin{array}{ll}\text { Y2 } & \text { Loyalitas pelanggan } \\ \text { Y1 } & =\text { Kepuasan pelanggan } \\ \text { X1 } & =\text { Kualitas Pelayanan }\end{array}$

b0, b1, b2 = Koefisien Regresi

$\mathrm{e}=$ Standard Error

2.

Koefisien

Determinasi

(R2)

Koefisiensi determinasi (R2) mengukur seberapa jauh kemampuan model dalam menerangkan variasi variabel dependen. Nilai koefisien determinasi adalah antara nol dan satu. Nilai R2 yang kecil berarti kemampuan variabel-variable independen dalam menjelaskan variasi variabel dependen amat terbatas. Nilai yang mendekati satu berarti variabel-variabel independen memberikan hampir semua informasi yang dibutuhkan untuk memprediksi variasi variabel dependen (Ghozali, 2009).

3.

Uji Simultan (Uji F)

Uji statistik $\mathrm{F}$ menunjukkan apakah semua variabel independen atau bebas yang dimasukkan dalam model mempunyai pengaruh secara bersama-sama terhadap variabel dependen atau terikat.

4.

Uji Parsial (Uji t)

Uji statistik $\mathrm{t}$ menunjukkan seberapa jauh pengaruh satu variabel penjelas atau independen secara individual dalam menerangkan variasi variabel dependen (Ghozali, 2009). Pengujian ini bertujuan untuk menguji pengaruh variabel bebas (kualitas pelayanan dan kepuasan nasabah) terhadap variabel terikat (loyalitas nasabah) secara terpisah ataupun bersama-sama.

\section{PEMBAHASAN}

\section{Uji Validitas}

Hasil uji validitas tersaji dalam berikut :

Tabel 2. Hasil uji validitas

\begin{tabular}{|c|c|c|c|c|}
\hline Variabel & Item & Nilai r hitung & Nilai r tabel & Keterangan \\
\hline Tangible & Item 1 & 0,651 & 0,196 & Valid \\
\hline & Item 2 & 0,834 & 0,196 & Valid \\
\hline & Item 3 & 0,695 & 0,196 & Valid \\
\hline & Item 4 & 0,720 & 0,196 & Valid \\
\hline Reliability & Item 1 & 0,718 & 0,196 & Valid \\
\hline & Item 2 & 0,742 & 0,196 & Valid \\
\hline & Item 3 & 0,833 & 0,196 & Valid \\
\hline & Item 4 & 0,732 & 0,196 & Valid \\
\hline Responsiveness & Item 1 & 0,846 & 0,196 & Valid \\
\hline & Item 2 & 0,912 & 0,196 & Valid \\
\hline & Item 3 & 0,862 & 0,196 &
\end{tabular}




\begin{tabular}{|c|c|c|c|c|}
\hline & Item 4 & 0,910 & 0,196 & Valid \\
\hline Assurance & Item 1 & 0,795 & 0,196 & Valid \\
\hline & Item 2 & 0,806 & 0,196 & Valid \\
\hline & Item 3 & 0,872 & 0,196 & Valid \\
\hline & Item 4 & 0,810 & 0,196 & Valid \\
\hline Empathy & Item 1 & 0,829 & 0,196 & Valid \\
\hline & Item 2 & 0,834 & 0,196 & Valid \\
\hline & Item 3 & 0,829 & 0,196 & Valid \\
\hline & Item 4 & 0,682 & 0,196 & Valid \\
\hline Kepuasan & Item 1 & 0,822 & 0,196 & Valid \\
\hline & Item 2 & 0,867 & 0,196 & Valid \\
\hline & Item 3 & 0,865 & 0,196 & Valid \\
\hline & Item 4 & 0,868 & 0,196 & Valid \\
\hline & Item 1 & 0,829 & 0,196 & Valid \\
\hline & Item 2 & 0,797 & 0,196 & Valid \\
\hline & Item 3 & 0,852 & 0,196 & 0,196 \\
\hline
\end{tabular}

Berdasarkan tabel diatas menunjukan bahwa nilai korelasi product moment ( $\mathrm{r}$ hitung) untuk masing-masing item pertanyaan lebih besar dari nilai $r$-tabel sebesar 0,196 (taraf signifikan 5\% dan $\mathrm{n}=100$ ), sehingga dapat disimpulkan bahwa item-item dari pernyataan tersebut dinyatakan valid dan dapat digunakan untuk penelitian selanjutnya.

3.

Uji Reliabilitas

Hasil pengujuan reliabilitas tersaji dalam tabel berikut :

Tabel 3. Hasil uji reliabilitas

\begin{tabular}{|l|c|c|}
\hline \multicolumn{1}{|c|}{ Variabel } & Nilai Alpha & Keterangan \\
\hline Kualitas Pelayanan & 0,957 & Reliabel \\
\hline Kepuasana Nasabah & 0,938 & Reliabel \\
\hline Loyalitas Nasabah & 0,924 & Reliabel \\
\hline
\end{tabular}

Berdasarkan tabel tersebut diatas, seluruh item pernyataan mempunyai nilai Cronbach's alpha diatas 0,60 sehingga dapat disimpulkan bahwa seluruh item pernyataan tersebut reliable atau handal.

3.

Uji Multikolineritas

Hasil uji multikolineritas tersaji dalam berikut :

Tabel 4. Hasil uji multikolinieritas

\begin{tabular}{|c|c|c|}
\hline Variabel & Tolerance & Variance Inflation Factor \\
\hline Kualitas & 0,195 & 5,133 \\
\hline Kepuasan & 0,195 & 5,133 \\
\hline
\end{tabular}

Berdasarkan tabel diatas, dilihat bahwa nilai variance inflation factor (VIF) dari masing-masing variabel independen kurang dari 10 dan nilai tolerance yang terbentuk diatas 0,1 maka dapat disimpulkan bahwa model regresi layak digunakan untuk penelitian selanjutnya.

\section{Analisis Regresi Linier Berganda}

\section{Hasil analisis jalur persamaan regresi 1}

Hasil uji regresi linier berganda untuk persamaan 1 (kualitas pelayan terhadap kepuasan nasabah) tersaji dalam berikut : 
Tabel 5. Hasil uji regresi linier berganda persamaan 1

\begin{tabular}{|l|r|r|r|}
\hline \multicolumn{1}{|c|}{ Variabel } & Koefisien Regresi & \multicolumn{1}{c|}{ T hitung } & \multicolumn{1}{c|}{ Sig. } \\
\hline Konstanta & 0,415 & 0,536 & 0,593 \\
\hline Kualitas Pelayanan & 0,956 & 20,125 & 0,000 \\
\hline Adjusted R Square & & 0,803 \\
F hitung & & 405,001 \\
Sig F & & $0,000^{\mathrm{b}}$ \\
\hline
\end{tabular}

Berdasarkan hasil analisis jalur substruktur 1 seperti yang disajikan pada tabel diatas. maka persamaan strukturalnya adalah sebagai berikut :

$\mathrm{Y} 1=\mathrm{b} 0+\mathrm{b} 1 \mathrm{X}+\mathrm{e}$

$\mathrm{Y} 1=0,415+0,956 \mathrm{X}+\mathrm{e}$

\section{Hasil Analisis Jalur Persamaan Regresi 2}

Hasil uji regresi linier berganda untuk persamaan 2 (kualitas pelayanan terhadap kepuasana dan loyalitas nasabah) tersaji dalam berikut :

Tabel 6. Hasil uji regresi linier berganda persamaan 2

\begin{tabular}{|l|r|r|r|}
\hline \multicolumn{1}{|c|}{ Variabel } & Koefisien Regresi & T hitung & \multicolumn{1}{c|}{ Sig. } \\
\hline Konstanta & 1,135 & 1,437 & 0,154 \\
\hline Kualitas Pelayanan & 0,479 & 4,366 & 0,000 \\
\hline Kepuasan Nasabah & 0,433 & 4,209 & 0,000 \\
\hline Adjusted R Square & & 0,787 \\
F hitung & & 179.028 \\
Sig F & & & $0,000^{\mathrm{b}}$ \\
\hline
\end{tabular}

Berdasarkan hasil analisis jalur substruktur 2 seperti yang disajikan pada tabel diatas, maka persamaan strukturalnya adalah sebagai berikut :

$\mathrm{Y} 2=\mathrm{b} 0+\mathrm{b} 1 \mathrm{X}+\mathrm{b} 2 \mathrm{Y} 1+\mathrm{e}$

$\mathrm{Y} 2=1,135+0,479 \mathrm{X}+0,433 \mathrm{Y} 1+\mathrm{e}$

\section{Hipotesis Pertama}

Hasil analisis jalur persamaan regresi 1 pengaruh kualitas pelayanan terhadap kepuasan nasabah dengan t hitung $(20,125)$ dan lebih besar dari t tabel $(1,983)$ atau tingkat signifikansi $(0,000)$ lebih kecil dari alpha $5 \%(0,050)$ menyatakan bahwa terdapat pengaruh yang nyata antara Kualitas Pelayanan terhadap Kepuasan Nasabah. Nilai signifikansi sebesar 0,000 menunjukkan bahwa tingkat kesalahan dalam menyatakan bahwa terdapat pengaruh kualitas pelayanan terhadap kepuasan nasabah adalah sebesar 0,0\%. Hasil analisis regresi menunjukkan nilai koefisien sebesar 0,956 dan bertanda positif signifikan menyatakan bahwa bentuk pengaruh kualitas pelayanan terhadap kepuasan nasabah adalah berbanding lurus yang berarti bahwa semakin tinggi faktor kualitas pelayanan yang dinilai oleh responden, maka akan meningkatkan kepuasan nasabah. Sebagaimana yang telah dijelaskan di atas, maka hipotesis pertama yang menduga bahwa kualitas pelayanan memiliki pengaruh secara langsung terhadap kepuasan nasabah di Bank XYZ diterima.

\section{Hipotesis Kedua}

Hasil analisis jalur persamaan regresi 2 pengaruh kepuasan nasabah terhadap loyalitas dengan thitung $(4,209)$ dan lebih besar dari t tabel $(1,983)$ atau tingkat signifikansi $(0,000)$ lebih kecil dari alpha $5 \%(0,050)$ menyatakan bahwa terdapat pengaruh yang nyata antara kepuasan nasabah terhadap loyalitas. Nilai signifikansi sebesar 0,000 menunjukkan bahwa tingkat kesalahan dalam menyatakan bahwa terdapat pengaruh Kepuasan nasabah terhadap loyalitas adalah sebesar $0,0 \%$. Nilai koefisien berdasarkan analisis regresi adalah sebesar 
0,433 dan bertanda positif signifikan menyatakan bahwa bentuk pengaruh Kepuasan terhadap loyalitas nasabah adalah berbanding lurus yang berarti bahwa semakin tinggi faktor kepuasan nasabah yang dinilai oleh responden, maka akan meningkatkan loyalitas nasabah. Sebagaimana yang telah dijelaskan di atas, maka hipotesis kedua yang menduga bahwa kepuasan nasabah memiliki pengaruh secara langsung terhadap loyalitas nasabah di Bank XYZ diterima.

\section{Hipotesis Ketiga}

Hasil analisis jalur persamaan regresi 2 kualitas pelayanan terhadap loyalitas nasabah dengan $t$ hitung $(4,366)$ dan lebih besar dari t tabel $(1,983)$ atau tingkat signifikansi $(0,000)$ lebih kecil dari alpha 5\% $(0,050)$ menyatakan bahwa terdapat pengaruh yang nyata antara kualitas pelayanan terhadap loyalitas nasabah. Nilai signifikansi sebesar 0,000 menunjukkan bahwa tingkat kesalahan dalam menyatakan bahwa terdapat pengaruh antara kualitas pelayanan terhadap loyalitas nasabah adalah sebesar $0,0 \%$. Berdasarkan hasil analisis regresi, nilai koefisien adalah sebesar 0,479 dan bertanda positif signifikan menyatakan bahwa bentuk pengaruh kualitas pelayanan terhadap loyalitas nasabah adalah berbanding lurus yang berarti bahwa semakin tinggi faktor kualitas pelayanan yang dinilai oleh responden, maka akan meningkatkan loyalitas nasabah. Sebagaimana yang telah dijelaskan di atas, maka hipotesis ketiga yang menduga bahwa kualitas pelayanan memiliki pengaruh secara langsung terhadap loyalitas nasabah di Bank XYZ diterima.

\section{KESIMPULAN}

Kesimpulan dari penelitian ini adalah sebagai berikut :

1) Kualitas pelayanan berpengaruh positif dan signifikan terhadap kepuasan nasabah Bank XYZ Artinya, semakin baik kualitas pelayanan yang diberikan oleh Bank XYZ maka dapat meningkatkan kepuasan nasabah, sebaliknya semakin buruk kualitas pelayanan yang diberikan maka semakin rendah pula kepuasan yang dirasakan oleh nasabah Bank XYZ.

2) Kepuasan berpengaruh positif dan signifikan terhadap loyalitas nasabah Bank $X Y Z$ Artinya, semakin tinggi tingkat kepuasan yang dirasakan nasabah Bank XYZ maka akan semakin tinggi tingkat loyalitas nasabah, sebaliknya semakin buruk kepuasan yang dirasakan maka semakin rendah pula tingkat loyalitas nasabah terhadap Bank XYZ.

3) Kualitas pelayanan berpengaruh positif dan signifikan terhadap loyalitas nasabah pada Bank XYZ. Artinya, semakin baik kualitas pelayanan yang diberikan kepada nasabah, maka akan semakin tinggi tingkat loyalitas nasabah terhadap Bank XYZ, dan sebaliknya semakin buruk kualitas pelayanan yang diberikan maka akan semakin rendah pula tingkat loyalitas nasabah terhadap Bank XYZ.

\section{SARAN}

Berdasarkan pembahasan dan simpulan dalam penelitian ini, adapun saran untuk perbaikan yang dapat disampaikan kepada Bank XYZ sebagai berikut:

1) Berdasarkan hasil analisis yang dilakukan, dinyatakan kualitas pelayanan berpengaruh positif dan signifikan terhadap kepuasan nasabah. Dari deskripsi variabel penelitian tersebut, terlihat bahwa responden merasa puas terhadap pelayanan yang diberikan oleh Bank XYZ. Kualitas pelayanan yang baik harus terus ditingkatkan sekalipun nasabah sudah merasa puas akan pelayanan yang diberikan Bank XYZ.

2) Kepuasan dinyatakan berpengaruh positif dan signifikan terhadap loyalitas nasabah Bank XYZ, maka dari itu Bank XYZ harus berusaha untuk dapat menciptakan nasabah yang tidak hanya sekedar puas terhadap perlayanan yang diberikan, dengan harapan memperoleh nasabah yang loyal terhadap perusahaan. 
3) Kualitas layanan berpengaruh signifikan terhadap loyalitas nasabah, maka manajemen perlu melakukan strategi yang berpusat pada kualitas layanan untuk mendapatkan nasabah yang loyal terhadap Bank XYZ.

\section{DAFTAR PUSTAKA}

Akbar, M.M., and Parvez, N. 2009. Impact of Services Quality, Trust, and Customer Satisfaction on Customer Loyalty, ABAC Journal, Vol. 29, No. 1, pp. 24-38.

Al-Rousan, M. Ramzi dan Badaruddin Mohamed. 2010. Customer Loyalty and the Impacts of Service Quality: The Case of Five Star Hotels in Jordan. journal of Business and Economic Sciences, Vol. 5, pp. 202-208.

Bedi, M. 2010. An Integrated Framework for Service Quality, Customer Satisfaction and Behavioral Responses in Indian Banking Industry-a 98 Comparison of Public and Private, Journal of Services Research, Vol. 10 No. 1, pp. 157-172.

Ganguli, Shirshendu dan Sanjit Kumar Roy. 2011. Generic Technology-based service quality dimensions in banking impact on customer satisfaction and loyalty. International Journal of Bank Marketing Vol. 29 No. 2.

Ghozali, Imam. 2009. “Aplikasi Analisis Multivariate dengan Program SPSS “. Semarang : UNDIP

Kotler, P. dan Keller, K.L. 2007. Manajemen Pemasaran. Jilid 1 dan 2. Jakarta: PT Indeks.

Lovelock, C.H dan Wright, L.K. 2007. Manajemen Pemasaran Jasa. Edisi Bahasa Indonesia. Jakarta: PT Indeks.

Mosahab, R., Mahamad, O., and Ramayah, T. 2010. Service Quality, Customer Satisfaction and Loyalty: A Test of Mediation, International Business Researc, Vol. 3, No. 4, pp. 72-80.

Tjiptono, F. 2007. Manajemen Jasa. Edisi Keempat. Yogyakarta: Andi Offet. 
